\title{
Assessment of the Safety Maturity Level of Construction Companies in Nigeria: EFQM Approach
}

\section{Oladinrin Timo Olugbenga ${ }^{1 *}$, Chukwurah Olisa Patrick ${ }^{2}$, Makanjuola Sina Abayomi ${ }^{3}$}

${ }^{1}$ Department of Building and Real Estate,

The Hong Kong Polytechnic University, Kowloon, HONG KONG

${ }^{2}$ Department of Quantity Surveying,

Federal University of Technology, Akure, NIGERIA

${ }^{3}$ Department of Building,

Federal University of Technology, Akure, NIGERIA

*Corresponding Author

DOI: https://doi.org/10.30880/ijscet.2019.10.01.002

Received 19 Julai 2018; Accepted 01 March 2019; Available online 01 June 2019

Abstract:Air movement is one of the important parameter to establish a good indoor thermal condition. Due to the public environmental concern, people are becoming more interested on turning to the natural sources in achieving the parameters. With a good design approach considering the matters, building is expected to be able to provide good indoor natural ventilation flow inside, hence keeping comfort to its habitable spaces. As being studied before, there are type of houses that contribute to its indoor natural ventilation. However, a proper design solution may still required in determining the design elements to be used. This research defined the significant elements as a proper specified attributes which were observed in case studies. Three categories of tropical houses were studied under the category of vernacular house, contemporary house with vernacular element and contemporary house. Spaces of the houses that indicate good indoor natural ventilation performance were observed on the presence of the specified attributes. Based on the analysis, wind catcher element was found to be the most significant attribute to contribute the maximum to indoor natural ventilation. Wide opening was also found to be significant especially with those with louvers. It is also interesting to find how indoor layout design also significantly giving impact on the performance. Therefore, besides concerning on how to extract the outdoor air flow into building, it is also important to manage the indoor air flow effectively to benefit the occupants.

Keywords: natural ventilation, indoor natural ventilation performance 


\section{Introduction}

Health and safety issue is a global phenomenon, cutting across various industries with varying degrees of impact. Of all the industries, construction is reputed to be the most hazardous workplace with significant health and safety risks (Smallwood, Haupt\&Shakantu, 2008; Muiruri\&Mulinge, 2014; EU-OSHA, 2004). Globally, the fatality rate on construction workplaces is two to three times higher than in the other industries, while exposure to serious injury triples that of fatal accidents (EU-OSHA, 2004). Although tremendous efforts have been made to improve health and safety performance, the construction industry still lagsbehind most other industries (Ringen, Van Duivenbooden, \&Melius, 2010). Specifically, the construction industry in Nigeria has been faced with various challenges such as cost overrun, time overrun, disputes, abandonment, and building collapse but safety issues remain a serious bane in the industry (Adedejiet al., 2016). National Safety Council in 2005, stated that the economic impact of fatal and nonfatal injuries amounted to $\$ 625.5$ billion that year. There are poor records of various accidents occurring in Nigeria, however, accidents on construction sites oftentimes make the headlines(Okoye, 2018). It was reported in 2005 that a storey building in Port Harcourt collapsed and not less than twenty workers died as a result, this was barely 24 hours after a similar incident occurred in Lagos (Opara, 2007).

The issues associated with construction safety, in general, validates the clamour for proper safety adherence by safety bodies and researchers worldwide(Zhang, 2003). The Nigerian construction industry, in particular, has not exactly dealt well with the issue of safety, a trend that has been found common in developing countries[ref]. Challenges faced by the construction industry no doubt has a major role in harnessing the benefits of globalization,however; one of the issues that suggest that the industry in developing nations may not be well prepared for the challenges of the future is safety [8]. Some of the safety challenges in the Nigerian construction industry are well documented in the literature (Agwuet al., 2014; Diugwu, Baba\&Egila, 2012; Umeokafor et ai., 2014). Several factors affecting the implementation of safety mechanism have been highlighted in the literature, ranging from the parts played by the administrative staff to the workers and even statutory authorities (Umeokafor et ai., 2014). Most of these researches have observed that safety procedures in Nigeria tend to be more reactive in nature i.e. waiting for the accidents to happen before anything is done.The fact that a construction job or work environment is considered as highly risky and hazardous does not mean that its susceptibility to accident is not controllable - this largely depends on "work situation" which is humanly controllable (Olutuase, 2014). This human element involves both the leadership and the employees under them. In the pursuit of a safe working environment for all personnel, an analysis needs to be done of existing working ethics, conditions, and programs already in place in other to offer proper guides on the way forward. This paper aims to utilize the European Foundation for Quality Management (EFQM) self-assessment excellence model to assess safety enablers, results and maturity level of construction firms andto provide an avenue for construction firms and outfits to assess their current safety level and proffer solutions on how to move forward. This is the first empirical inquiry on the assessment of safety practices level of construction companies in Nigeria.

\section{Literature Review}

\subsection{Nature of Occupational Health and Safety}

Construction health and safety is a global phenomenon. Data from anumber of industrialized countries shows that construction workers are three to four times morelikely than other workers to die from accidents at work (International Labour Organisation, 2009). Okoye\&Okolie (2014) revealed that health and safety performance of contractors affected the success of building projects in terms of delivery time, quality, cost, and productivity, while non-performance induced litigation/legal costs which inadvertently increased the overall building project cost. From the findings, it showed that stakeholders believed that the implementation of health and safety programmes and policies increased the overall project cost and as a result, health and safety programmes are rarely implemented on site. The study finally recommended that the stakeholders especially the contractors should look beyond the immediate effect of implementing health and safety programmes and policies and focus on their long-term comparative advantages which include quality reliability, profitability, and timely delivery. A study by Muhammad et al., (2015) also revealed that contractors are aware of the benefits of health and safety compliance and how it is connected to the scope of their operations. In addition, accident and injury rate in the Nigerian construction industry is high implying that the challenges facing Nigerian contractors and companies in terms of high cost incurred because of injuries and hazards on site are significant (Muhammad et al., 2015). Despite several efforts towards effective health and safety system in the construction industry of Nigeria, Okoye, Ezeokonkwo\&Ezeokoli (2016) found that accident occurrences are still on the increase on construction sites. 


\subsection{EFQM Excellence Model and Safety Assessment}

The issue of Total Quality Management (TQM) has been a major focus of the whole business world. This is not unexpected as the benefits derivable from it are basic in reasoning. Best performing companies will attract best employees, future investments and probably maximize share value (Vukomanovic, Ceric\&Radujković, 2007). The construction industry, being a business venture, is not exempted from this.TQM is a way of managing an organization in other to ensure the satisfaction at every stage of the needs and expectation of both internal and external customers i.e. shareholders, consumers of its goods and services, employees and the community in which it operates, by means of every job, every process being carried out right and safely(Latham, 1994; Watson, 2002). Key performance indicators (KPI) are utilized in the measurement and communication of performance among interested parties, such as investor, sub-contractor, clients, and employees. KPI presents a way of evaluating the effect of actions or concepts such as TQM in achieving goals for which they are set. Traditional performance measures were developed in the 20th century and were utilized as financial indicators such as annual revenue, income, profit, etc. as a unit of performance measurement. The set back of their use is that they are only able to measure and report already achieved impact and are unable to anticipate future result and thus improve future performance. This method of rating performance didn't allow construction organizations to assess their performance correctly and so they started to fall behind other concurrent parties (Freema, \& Beale, 1992). The key point for moving from a financial perspective has garnered the work from Kaplan and Norton -the authors of The Balanced Scorecard (BSC) (Vukomanovic, Ceric \&Radujković, 2007), which concluded that management had to shift focus from financial indicators in orderfor the long-term goals not to be compromised. A need for a balanced set of measures is now widely accepted. Balance should be made within every business aspect, not just the financial aspect alone. In the last two decades, many industries, mainly production, implemented new methods and paradigm of thinking, i.e. BSC, in order to improve performance and thus the business's efficiency and effectiveness.

The '80s brought about a shift in the focus of project performance criteria from the traditional "iron triangle" (time, cost and quality/scope), with the inclusion of project success as an important part of performance assessment (Vukomanovic, Ceric \&Radujković, 2007). This implied that success is multidimensional and all interested parties must achieve an agreed percentage level of success. USA introduced Malcolm Baldrige National Award whileEurope introducedthe EFQM Excellence award for the measure of organisational excellence (Watson, 2002). Both awards acknowledge the concept of TQM, and later became highly appreciated for encouraging continuous improvement. The EFQM excellence model is a tool dedicated to stimulating and assisting management in applying innovative principles of TQM suited to the European environment. Its aim is to improve the competitiveness of European private and public sector organisations. The EFQM was founded in 1988 and is committed to promoting quality as the fundamental process for continuous improvement within a business. According to EFQM, the main reason for companies to apply the EFQM Excellence Model is to pursue business excellence through TQM, thereby allowing them to compete successfully in European and global markets. According to José Ignacio Wert, the former President of the EFQM, in 2006 30,000 European organizations were using the EFQM self-evaluation model (Allur, 2010). Likewise, the EFQM claims in their webpage that the EFQM Excellence Model is being implemented by over 30,000 organisations in the world (EFQM, 2012).

The EFQM excellence model is a non-prescriptive framework based on 9 criteria which can be used to assess an organization's progress towards success. These 9 criteria are made up 5 enablers and 4 results which are allocated points on individual bases making up their weighting. The EFQM Excellence Model consists of 9 criteria and 32 sub-criteria. The five criteria on the left-hand side of Fig 1 are called "Enablers" and are concerned with how the organization performs in various activities. According to Hillman (Hillman, 1994), 'the enablers are those processes and systems that need to be in place and managed to deliver total quality'. The four criteria on the right of Fig 1 are concerned with the "Results" the organisation is achieving with respect to different stakeholders and this provides the measure of actual achievement. A critical review of literature on quality and safety management in construction (Loushineet al., 2006) revealed from a theoretical standpoint that, quality management and safety management programs have similar features within the context of construction studies. It was found that the literature supports the use of integrated safety and quality management in construction. This assertion is relevant as the success of any construction projects lies in the company's ability to deliver a quality product in a safe manner. In this light, researchers have employed quality management model such EFQM to investigate the interactions among five key enablers of construction safety culture, as well as the possible impact of each enabler on organisational safety goals over a period of time (Chinda, \& Mohamed, 2007; Mohamed \&Chinda, 2011). Assessing safety culture through the instrumentation of EFQM will enable construction organisations to formulate an effective safety implementation practice to accomplish their planned safety goals in the time frame. 


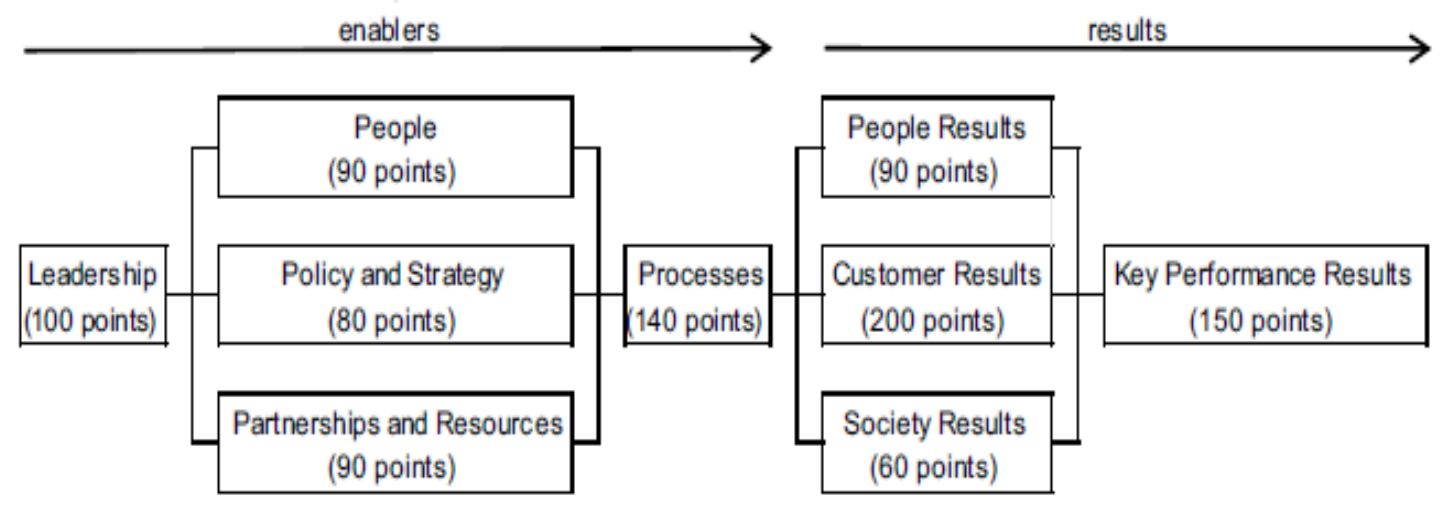

innovation and learning

\author{
Fig. 1 -The European Foundation for Quality Management (EFQM) excellence model \\ Source: (Chinda, 2012)
}

\title{
3. Methodology
}

Data was gathered from the field with the aid of structured questionnaires, which were issued to construction professionals. The questionnaire is divided into two sections; section one for demographic data, section two is concerning enabling factors and result factors. Five-point Likert scale was utilised in getting respondents' view on each of the attributes. The research population covered all stakeholders of the construction industry in Lagos State. These included all employers, professionals, workers, and personnel working in the construction sector.The reason for this was to reduce to a minimum, the probable bias of the contractors on their assessment through the objective view obtained from the consultant professionals across the field of construction including those professionals that are indispensable to the construction industry and also the most directly impacted by its activities with regards to safety measures - the skilled and non-skilled labour.

Convenience sampling was employed, and a sample of 260 respondents in the construction sector of Lagos State was approached in other to obtain data for analysis. Both hard and soft copy questionnaires were administered, and two hundred and thirty-nine (239) were retrieved and were good enough for analysis. This number is suitable for Exploratory Factor Analysis (EFA) because, according to Habing(2003,), elements (variables) to the respondent's ratio should not be less than 1:5. With 45 variables being the total number of variables to be analysed, a minimum total of 235 samples was to be gathered from the population.

\section{Results and Discussions}

\subsection{Results}

Table 1 shows the results of the test carried out on the data-set to confirm their adequacy for the usage of factor analysis. KMO test was carried out to this end, and a figure of 0.697 and 0.741 was gotten respectively for both enablers and result. The Kaiser-Meyer-Olkin Measure of Sampling Adequacy according to (Vukomanovica, Radujkovica \& Nahoda, 2014), indicates the proportion of variance in the variables that might be caused by underlying factors. With that, high values (close to 1.0) indicate that further analysis can be carried out but if the value is less than 0.50, the results will be questionable. Thus, for this analysis, the sample size is adequate. The Bartlett's test of sphericity indicatesthe level at which the variables are unrelated and therefore unsuitable for structure detection. Values of significance level less than 0.05 indicate that factor analysis may be useful (Vukomanovica, Radujkovica \& Nahoda, 2014). For both enablers and results, the attributes were found to have a significance of under 0.05 (0.001) hence are suitable for further analysis. 
Table 1 -Test for sample adequacy for enablers and results

\begin{tabular}{lll}
\hline & KMO test & Bartlett's test \\
\hline Enablers & .697 & .000 \\
Results & .741 & .000 \\
\hline
\end{tabular}

Table 2 shows the results of the exploratory factor analysis carried out on the 30 attributes listed as enablers in other to fashion out five headings under those factors as indicated by the EFQM model. The extraction was done via the use of principal components analysis with the use of varimax rotation. The weak attributes were weeded out via the use of a cut-off loading of 0.4 to remove weak loading (Chinda, 2012). After the extraction and rotation, a total of five factors were extracted, which covered about almost $63.8 \%$ of the variance and with an Eigenvalue larger than 1. There was a major observed redistribution of the attributes, this mandated the need for the conduction of reliability statistics to confirm the adequacy of the redistribution. The resultant grouping for the enablers showed a remarkable improvement in the Cronbach score that was observed before the use of factor analysis for the groupings. These were aptly named using the EFQM factors for enablers as;Leadership, Policy, People, Partnership and Resources, andProcesses andStrategy.

Table 2 -Factor analysis for the 30 enablers

\begin{tabular}{|c|c|c|c|c|c|}
\hline Attributes & Leadership & Policy & People & $\begin{array}{l}\text { Partnership } \\
\text { and } \\
\text { Resources } \\
\end{array}$ & $\begin{array}{l}\text { Process and } \\
\text { Strategy }\end{array}$ \\
\hline Benchmarking system & .809 & & & & \\
\hline Consultative style & .776 & & & & \\
\hline Safety perception & .732 & & & & \\
\hline Adequate training & .672 & & & & \\
\hline Management feedback & .570 & & & & \\
\hline Partnership selection & .528 & & & & \\
\hline Workers involvement & & .744 & & & \\
\hline Risk assessment & & .736 & & & \\
\hline Safety program & & .622 & & & \\
\hline Safety booklets & & .570 & & & \\
\hline Updated safety standards & & .552 & & & \\
\hline Worker recognition & & & .742 & & \\
\hline Peer review & & & .708 & & \\
\hline Employee feedback & & & .629 & & \\
\hline Team effort & & & .624 & & \\
\hline Role model & & & .597 & & \\
\hline Job description & & & .552 & & \\
\hline Accident records & & & & .777 & \\
\hline Adequate PPE & & & & .768 & \\
\hline Adequate safety resource & & & & .696 & \\
\hline Partnership awareness & & & & .690 & \\
\hline Partnership cooperation & & & & .632 & \\
\hline Safety goal & & & & .592 & \\
\hline Management commitment & & & & .571 & .436 \\
\hline Safety accountability & & & & & -.651 \\
\hline Safety priority & & & & & .650 \\
\hline Adequate supervision & & & & & .458 \\
\hline Safety empowerment & & & & & .455 \\
\hline Safety compliance & & & & & .429 \\
\hline
\end{tabular}


Table 3 shows the results of the exploratory factor analysis carried out on the 17 attributes of results of safety practices. The extraction was done via the use of principal components analysis with the use of varimax rotation. The weak attributes were weeded out via the use of a cut-off loading of 0.4 to remove weak loading and leave a sensible bit of data for use (Chinda, 2012). After the extraction and rotation, a total of four factors were extracted which covered about almost $67.4 \%$ of the variance and with an Eigenvalue larger than 1 . There was also observed a redistribution of elements that were also aptly named under the headings of EFQM results.

Table 3 - Factor analysis for the 17 results

\begin{tabular}{|c|c|c|c|c|}
\hline Attributes & People Results & $\begin{array}{l}\text { Customer } \\
\text { Results }\end{array}$ & $\begin{array}{l}\text { Societal } \\
\text { Results }\end{array}$ & $\begin{array}{l}\text { Specific } \\
\text { Performance Result }\end{array}$ \\
\hline Worker satisfaction & .821 & & & \\
\hline Safe work behaviour & .739 & & & \\
\hline Customer perception & & .766 & & \\
\hline Increased competitiveness & & .729 & & \\
\hline Organisational performance & & .707 & & \\
\hline Client expectation & & .576 & & \\
\hline Social costs & & & .852 & \\
\hline Accident reduction & & & .829 & \\
\hline Customer satisfaction & & & & .877 \\
\hline Customer relationship & & & & .754 \\
\hline Loyal customer & & & & .664 \\
\hline Social image & & & & .664 \\
\hline Social image & & & & .654 \\
\hline Total cost reduction & & & & .635 \\
\hline Public cooperation & & & & .587 \\
\hline Turnover reduction & & & & .578 \\
\hline Better communication & & & & .532 \\
\hline
\end{tabular}

The results were also subjected to reliability test in other to determine their suitability. As suggested by (Chinda, 2012), this was expected to be greater than 0.7 for reliability. The reliability analysis showed a remarkable improvement in the reliability of the grouping after factor analysis as compared to before factor analysis was carried out as shown in Table 4.

Table 4 - Factor reliability test

\begin{tabular}{lcc}
\hline Attributes & Cronbach's Test Score & \\
\hline Enablers & Before Factor Analysis & After Factor Analysis \\
Leadership & 0.542 & 0.745 \\
Policy & 0.732 & 0.756 \\
People & 0.789 & 0.806 \\
Partnership and Resources & 0.762 & 0.877 \\
Process & 0.791 & 0.849 \\
Results & & \\
People results & 0.545 & 0.623 \\
customer & 0.748 & 0.782 \\
Societal results & 0.693 & 0.803 \\
Specific performance results & 0.703 & 0.858 \\
\hline
\end{tabular}

Table 5 shows the mean distribution for the safety enablers. Based on the respondents' view, a relative above average performance is observed based on the mean weighting of 5 . The "Process" and "People" factor is rated highest with about 3.73 and 3.74 mean item score respectively and the least rated is the "leadership" with 3.42 mean item score. This trend shows that the processes engaged in construction companies and the acts of workers are the most effective enablers for ensuring safety i.e. holding the workers accountable for their safety, ensuring compliance and supervising them adequately. 
On the other hand, leadership in the Lagos construction companies currently still contribute the least to the promotion of safety.

Table 5 - Factor weighting for enablers

\begin{tabular}{|c|c|c|c|c|}
\hline Factors & Attributes & $\begin{array}{c}\text { Mean } \\
\text { Weighting }\end{array}$ & $\begin{array}{l}\text { Factor } \\
\text { Mean }\end{array}$ & Ranking \\
\hline \multirow[t]{7}{*}{ Leadership } & Benchmarking system & 3.3083 & & \\
\hline & Consultative style & 3.2125 & & \\
\hline & Safety perception & 3.5667 & & \\
\hline & Adequate training & 3.4583 & & \\
\hline & Management feedback & 3.7583 & & \\
\hline & Partnership selection & 3.2383 & & \\
\hline & & & 3.42 & 5 \\
\hline \multirow[t]{6}{*}{ Policy } & Workers involvement & 3.8417 & & \\
\hline & Risk assessment & 3.7875 & & \\
\hline & Safety program & 3.6750 & & \\
\hline & Safety booklets & 3.2083 & & \\
\hline & Updated safety standards & 3.5833 & & \\
\hline & & & 3.62 & 3 \\
\hline \multirow[t]{7}{*}{ People } & Worker recognition & 3.4458 & & \\
\hline & Peer review & 3.6458 & & \\
\hline & Employee feedback & 4.0750 & & \\
\hline & Team effort & 3.7458 & & \\
\hline & Role model & 3.9333 & & \\
\hline & Job description & 3.6167 & & \\
\hline & & & 3.74 & 1 \\
\hline \multirow{9}{*}{$\begin{array}{l}\text { Partnership and } \\
\text { resources }\end{array}$} & Accident records & 3.3792 & & \\
\hline & Adequate PPE & 3.5375 & & \\
\hline & Adequate safety resource & 3.7750 & & \\
\hline & Partnership awareness & 3.8487 & & \\
\hline & Adequate financial resource & 3.6958 & & \\
\hline & Partnership cooperation & 3.7750 & & \\
\hline & Safety goal & 3.5625 & & \\
\hline & Management commitment & 3.3792 & & \\
\hline & & & 3.62 & 3 \\
\hline \multicolumn{5}{|l|}{ Process and } \\
\hline \multirow[t]{6}{*}{ Strategy } & Safety accountability & 3.3417 & & \\
\hline & Safety priority & 3.8703 & & \\
\hline & Adequate supervision & 4.1083 & & \\
\hline & Safety empowerment & 3.8917 & & \\
\hline & Safety compliance & 3.8333 & & \\
\hline & & & 3.73 & 2 \\
\hline
\end{tabular}

Table 6 presents an indicator of the "result" factors achieved as a result of the enablers influence. The highest performance is seen in terms of the "Societal" and "Specific performance" results with mean item scores of 3.72 and 3.73 respectively. The least performance is recorded in the "People" results, with the mean item score of 3.61 and customer results with 3.65, which indicates that the worker satisfaction and safe work behaviour are the least affected with the enablers undertaken. 
Table 6 - Factor weighting for results

\begin{tabular}{|c|c|c|c|c|}
\hline Factors & Attributes & $\begin{array}{c}\text { Mean } \\
\text { weighting }\end{array}$ & Factor mean & Ranking \\
\hline \multirow[t]{3}{*}{ People results } & Worker satisfaction & 3.6125 & & \\
\hline & Safe work behaviour & 3.6000 & & \\
\hline & & & 3.61 & 4 \\
\hline \multirow{5}{*}{$\begin{array}{l}\text { Customer } \\
\text { results }\end{array}$} & Customer perception & 3.6125 & & \\
\hline & Increased competitiveness & 3.7792 & & \\
\hline & Organisational performance & 3.6208 & & \\
\hline & Client expectation & 3.6042 & & \\
\hline & & & 3.65 & 3 \\
\hline \multirow{3}{*}{$\begin{array}{l}\text { Societal } \\
\text { results }\end{array}$} & Social costs & 3.8875 & & \\
\hline & Accident reduction & 3.5667 & & \\
\hline & & & 3.72 & 2 \\
\hline \multirow{10}{*}{$\begin{array}{l}\text { Specific } \\
\text { performance } \\
\text { results }\end{array}$} & Customer satisfaction & 3.5458 & & \\
\hline & Customer relationship & 3.5125 & & \\
\hline & Loyal customer & 3.9583 & & \\
\hline & Social image & 4.0333 & & \\
\hline & Social image & 3.8875 & & \\
\hline & Total cost reduction & 4.0375 & & \\
\hline & Public cooperation & 3.5542 & & \\
\hline & Turnover reduction & 3.2708 & & \\
\hline & Better communication & 3.7792 & & \\
\hline & & & 3.73 & 1 \\
\hline
\end{tabular}

Table 7 shows the application of all the EFQM model criteria in order to assess the performance level of construction companies based on the respondents' views. A score of 723 out of 1000 points expected by EFQM was achieved which amount to $72.3 \%$ safety performance level of the construction companies in Lagos state.

Table 7 - Assessment of safety level using The EFQMmodel

\begin{tabular}{lllll}
\hline Factors & $\begin{array}{l}\text { Maximum } \\
\text { Score }\end{array}$ & $\begin{array}{l}\text { Weighting } \\
\text { Factor }\end{array}$ & $\begin{array}{l}\text { Factor } \\
\text { Mean }\end{array}$ & $\begin{array}{l}\text { Companies' } \\
\text { Performance }\end{array}$ \\
\hline Leadership & 100 & 20 & 3.42 & 68.40 \\
Policy and Strategy & 90 & 18 & 3.62 & 65.16 \\
People & 80 & 16 & 3.74 & 59.84 \\
Partnerships and Resources & 90 & 18 & 3.62 & 65.16 \\
Processes & 140 & 28 & 3.73 & 104.44 \\
People Results & 90 & 18 & 3.61 & 64.98 \\
Customer Result & 200 & 40 & 3.65 & 146.00 \\
Society Results & 60 & 12 & 3.72 & 44.76 \\
Key Performance Results & 150 & 28 & 3.73 & 104.44
\end{tabular}


Also, the EFQM excellence model promotes the use of a five-level maturity scale for the assessment of excellence (Chinda, 2012) as categorised in the following.

- Uncommitted level: 0-249 points;

- Drifter level: 250-499 points;

- Improver level: 500-749 points;

- Award winner level: 750-999 points;

- World-class level: this level has a single score

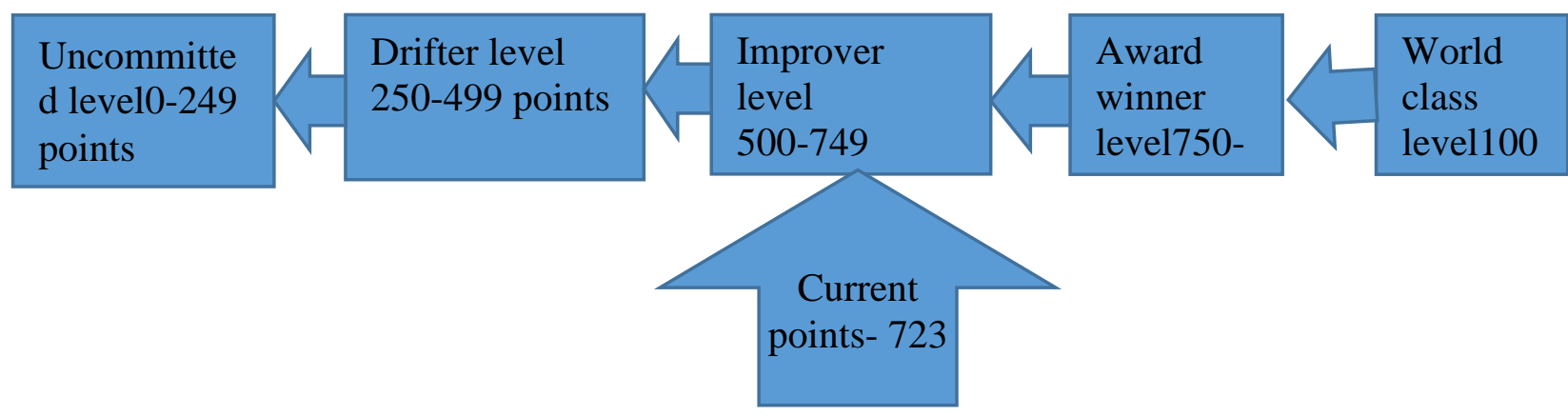

Fig. 2 - Maturity level of construction companies in Lagos State, Nigeria

Figure 2 represents the scale in relation to the score attained by the construction companies in Lagos state. The current maturity level is situated at level three i.e. the improver level. This indicates that there is still room for improvement in all sectors of the companies in Lagos state and that it is yet to reach the award-winning level let alone world class level.

Table 8 - Percentage scores attained by Lagos State Construction Companies

\begin{tabular}{lccc}
\hline Factor & $\begin{array}{l}\text { Maximum Score } \\
\text { (Points) }\end{array}$ & $\begin{array}{l}\text { Lagos Companies' } \\
\text { Score }\end{array}$ & Percentage (\%) \\
\hline Leadership & 100 & 68.40 & 68.40 \\
Policy and Strategy & 90 & 65.16 & 72.40 \\
& & & 74.80 \\
People & 80 & 59.84 & 72.40 \\
Partnerships and & 90 & 65.16 & 74.60 \\
Resources & 140 & 104.44 & 72.20 \\
Processes & 90 & 64.98 & 73.00 \\
People Results & 200 & 146.00 & 74.60 \\
Customer Results & 60 & 44.76 & 69.63 \\
Society Results & 150 & 104.44 & \\
Key Performance Results & & & \\
& & & \\
\hline
\end{tabular}

Table 8 gives a representation of the relative scores attained by the Lagos state construction companies to the maximum scores attainable under each factor based on the EFQM excellence model. The factors are all brought to a common ground of $100 \%$.

Figure 3 offers a relation of the attained scores by the Lagos state construction companies to the EFQM criteria. Thus in the evaluation, the strongest enabler lies with the People enabler $74.8 \%$ followed closely by the Process and strategy at $74.6 \%$. Two of the remaining enablers (i.e. Policy and Partnership and Resources) are around 70\% mark. The least contributing enabler lies with the Leadership enabler. These serve to imply that construction companies in Lagos depend more on workers (People) and Processes undertaken to ensure safety. Hence, there indicates a need for improvement in the activities of the management (leadership) towards safety, which will directly translate to better Policymaking and an 
improvement in the Partnership and Resources enablers respectively. Similarly, figure 3 also compares safety achievement in terms of results from the respondents' companies to EFQM standard measurement points. The difference in the measurement signifies the extent of the effort required to improve safety culture in construction companies.

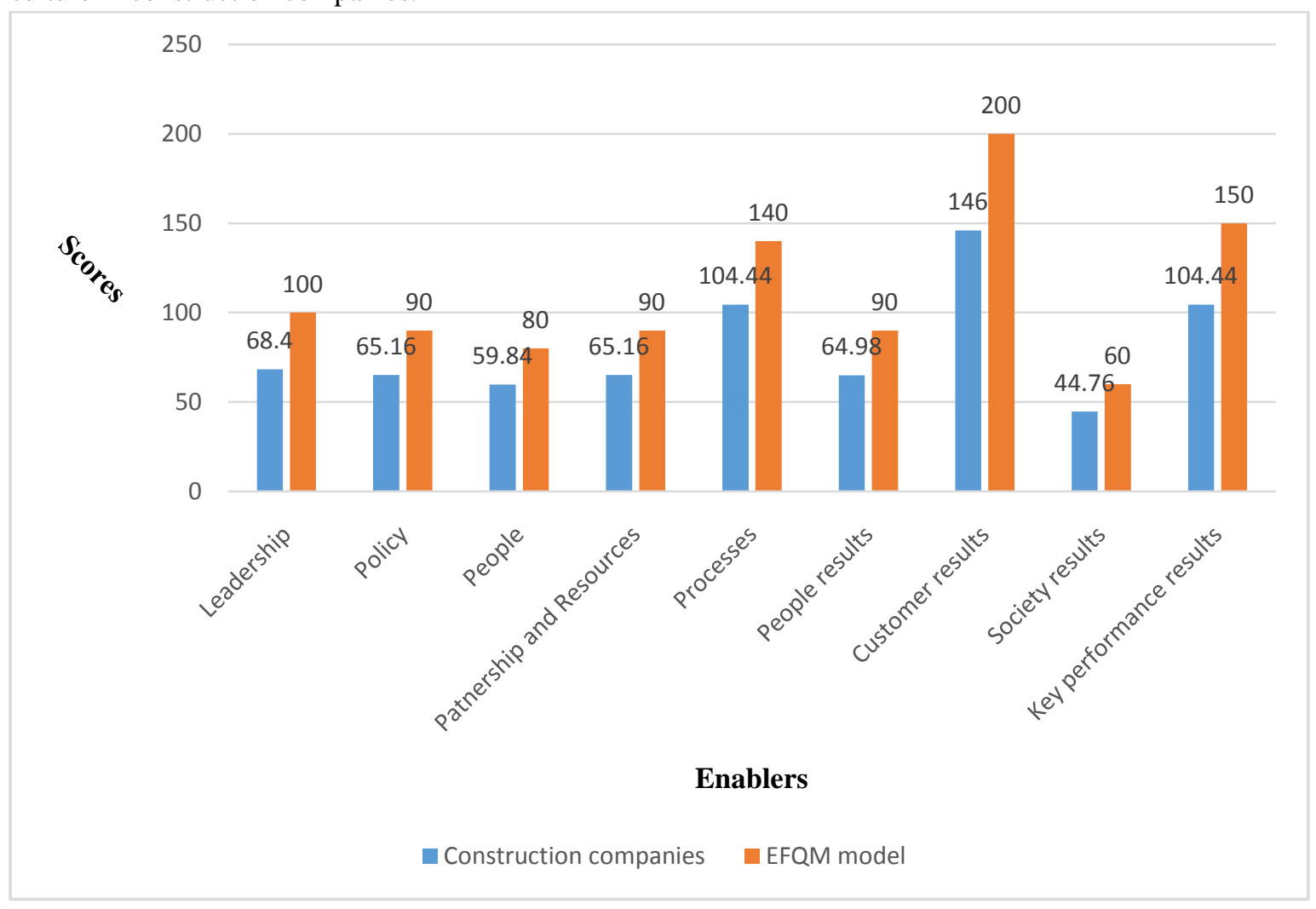

Fig. 3 -Construction companies’ enabler scores toward EFQM criteria

\subsection{Discussions}

The objective here was to seek the view of industry players on the level of safety exhibited in construction companies in Lagos state, Nigeria. From the view of the respondents using the EFQM excellence model, the companies were awarded an approximate score of $73 \%$. This shows an improvement compared to the low level of safety recorded by Olatunji, Aje\&Odugboye(2007) as far as Lagos state is concerned. However, there is still a lot of room for improvement for the Lagos construction companies as indicated on the EFQM excellence model scale. The score also implies that the companies are still at the improver level, which is two levels away from world-class excellence. Based on scores gained in the criteria, improving measures in all criteria is essential for this organization, especially the leadership enabler and people results. This will be discussed in detail below.

\subsubsection{Leadership}

Findings from the attributes extracted under leadership from the factor analysis conducted. Shows that leadership enabler is the least contributor to safety in the construction companies with $64 \%$ on $100 \%$ scale compared to the EFQM criteria for leadership. The mean weighting of each attribute indicates that management of construction companies have much to do in the areas of consultation and partnering in order to enhance safety performance as the two attributes scored lowest with the mean item score of 3.21 and 3.24 respectively. Hence, improvement in these attributes and the others such as benchmarking system, safety perception, adequate training, and management feedback, will go a long way in improving the other factors. This is in accordance with Chia-Kuang (2012) which ranked management activities as foremost among the factors affecting safety. 


\subsubsection{Policy}

The score for the policy was $72.4 \%$ as compared to the EFQM criteria for it. The availability of safety booklets to workers as a policy had the least item score of 3.21, signifying that the policy of the companies had yet to fully implement the allocation of safety booklets to their employees. Other attributes such as workers' involvement, risk assessment, safety program, and updated safety standards equally need decisive attention if a safety culture must be improved upon. This is in line with the summation of the study conducted by Mansir (2014) that contractors in Nigeria were yet to fully integrate the implementation of health and safety plan.

\subsubsection{People}

People enabler scored the highest with $74.8 \%$, this implies that in the present situation, construction companies depend most on its employees to ensure their own safety. Surprisingly, worker recognition criterion has the lowest score of 3.44. The finding still holds that employees play a significant role in the safety performance of construction companies. This is contrary to the views of Okoye (2018) who identified the human factors as the least contributor to safety.

\subsubsection{Partnership and Resources}

The score for partnership and resources is $72.4 \%$ as compared to the EFQM criteria for it, same with policy enabler. In the distribution of the mean item scores for attributes under this enabler, notably the occurrence of accident records being kept by construction companies and management commitment have the same lowest mean item score of 3.37, which is in line with the observations of various researchers (Agwuet al., 2014; Akinkunmi, 2006). Partnership awareness and adequate safety resource and financial resource were the highest rated, which indicates that the companies focus majorly on quantitative safety implementation i.e. the use of signs, gears, etc. and less attention paid to qualitative measures such as safety record keeping and safety goal, both of which reflect on the management commitment as it also ranked lowest.

\subsubsection{Processes}

The Process enabler has the second highest score of $74.6 \%$. This implies that according to present situation, construction companies in Lagos depend heavily also on processes to ensure safety, chief among the attributes is 'supervision' which ranked highest with the mean item score of 4.11 while safety accountability ranked lowest with the mean item score of 3.34. The issue of safety accountability generally cut across all management level. Attaining and maintaining a high level of safety culture requires deliberate attentionto safety practice accountability.

\subsubsection{Results}

In terms of the results of enablers undertaken by the construction companies in Lagos state, Nigeria, it is observed that the society remain the highest beneficiary of the safety enablers while the workers are the least satisfied with the enablers undertaken. This view is in line with the opinion of Idoro\&Iroroakpo (2011) and Idoro (2008) that the main benefits of safety are reflected in the society. Based on scores gained in the criteria, improving measures in all criteria is essential for the organization, especially in the people results.

\subsubsection{Maturity level of Lagos state construction companies}

The objective here was to assess the maturity level of construction companies in Lagos state, Nigeria using the EFQM excellence model. A total score of 723 was attributed to construction companies in terms of safety maturity level which indicates that the construction companies in Lagos are currently at the improver level. This could be attributed to the degree of development being recorded across all sectors of the state and the influx and establishment of multi-national companies. The finding is similar to the summation of (Akinkunmi, 2006). 


\section{Conclusions}

This study has assessed the level of safety exhibited by construction companies in Lagos. The assessment has led to the following conclusions. The study revealed that the construction companies in Lagos are currently at improver level according to the EFQM maturity scale. The study also revealed that people enabler factor are currently the most contributors to safety while leadership enabler is the least contributor. Regarding result criteria, the society is the most impacted by the measures put in place by the construction companies while workers are the least satisfied. It was discovered that there is a probable definite relationship with safety enablers and results exhibited by construction companies in Lagos state. Based on the findings from the study, it can be suggested that construction companies in Lagos state should generally invest more in safety attributes, by placing much focus on leadership and processes and resources enablers. There should be an avenue for the companies to evaluate their growth through the use of selfassessment models such as EFQM excellence model, in other to take stock of happenings and current level of activities and achievement for the purpose of performance review and improvement. Due to the relationship between enablers and result, companies should invest in safety enablers, over-looking the initial cost implication to reap the long-term benefits as there lies the effectiveness of the implementation. However, there is a limitation in this study in that convenience sampling was utilised in the data collection. The aim was to get as many respondents as possible that are knowledgeable on the subject matter. This is to minimise bias by focusing on the top management alone. This study was limited to the assessment of the safety level of top construction companies in Lagos State, Nigeria. The scope of the study could be widened to include other agents in the construction industry such as suppliers, consultants, and safety professionals, and the study area could be extended to other locations. Efforts could also be made to streamline the assessment of the contractors to their different tiers such as main contractors and sub-contractors as their influence on safety performance might be different. The instrument used for this research is not all encompassing as it deals more with the "quality of safety" thanwith the intrinsic safety itself. Hence, practitioners may have different opinions about the evaluation of safety. However, the application questionnaire and the EFQM methodused for the Health and Safety evaluation is flexible, hence practitioners can adapt the approach to any given scenario.

\section{Acknowledgement}

The authors would like to acknowledge the Hong Kong Polytechnic University, Hong Kong and Federal University of Technology, Nigeria.

\section{References}

Adedeji, A. O., Tunji-Olayeni, P. F., Amusan, L. M., O.Omuh, I., Ojelabi, R. A., \&Oyeyipo, O. O. (2016). Safety Cultured Industry Through theIntegration of Occupational Health and Safety (OHS) Courses in the Built Environment Curriculum. Proceedings of INTED2016 Conference (pp. 5811-5823). Spain: INTED Press.

Agwu, Okechukwu, M., Olele, \&Enoh, H. (2014). Fatalities in the Nigerian Construction Industry: A Case of Poor Safety Culture. British Journal of Economics, Management \& Trade, 4(3), 431-452.

Akinkunmi, O. O. (2006). An Appraisal of Safety Management in the Nigerian Construction Industry. Unpublished Post-graduateDiplomaThesis submitted to the Quantity Surveying Department, Federal University of Technology Akure.

Allur, E. (2010). The Dissemination of the EFQM. Review of International Comparative Management Volume 11, Issue 5, 971-979.

Chia-Kuang Lee, Y. J. (2012). Prioritization of Factors Influencing Safety Performance on Construction Sites: A Study Based on Grade Seven (G7) Main Contractors’ Perspectives. Pahang: University of Malaysia.

Chinda, T. (2012). A Safety Assessment Approach Using Safety enablers and results. International Journal of Occupational Safety and Ergonomics, 18(3), 343-361.

Chinda, T., \& Mohamed, S. (2007). Causal relationships between enablers of construction safety culture. In Proceedings of the 4th International Conference on Construction in 21st Century: Accelerating Innovation in Engineering, Management and Technology, Gold Coast, Australia (pp. 11-13). 
Diugwu, I. A., Baba, D. L., \&Egila, A. E. (2012). Effective Regulation and Level of Awareness: An Exposé of the Nigeria’s Construction Industry. Open Journal of Safety Science and Technology, 140-146.

EFQM (2012). EuropeanFoundation for QualityManagement. Brussels.

EU-OSHA (2004). European Agency for Safety and Health at Work, Building in Safety, Luxembourg: Publications Office of the European Union, Magazine 7.

Freeman, M., \& Beale, P. (1992). Measuring ProjectSuccess. Project Management Journal, 23(1), 8-17.

Habing, \& $\quad$ B. (2003,). Exploratory Factor Analysis. Retrieved from http://www.stat.sc.edu/ habing/courses/530EFA.pdf

Hillman G.P. (1994). Making Self-assessment Success. Total Quality Management, Vol. 6, 29-31.

Idoro, \&Iroroakpo, G. (2011). Effect of Mechanisation on Occupational Health and Safety Performance in the Nigerian Construction Industry. Journal of Construction in Developing Countries, 16(2), 27-45.

Idoro, G. (2008). Health and Safety Management Efforts as Correlates Performance in the Nigerian Construction Industry. Journal of Civil Engineering and Management, 14(4), 277-285.

International Labour Organisation (2009). World Day for Safety and Health at Work: Facts onSafety and Health at work. Retrieved January4, 2019 from http://www.ilo.org/factsonsafety at work.

Latham, M. S. (1994). Constructing the team - . Final reports of the government/industry review of procurement and contractual arrangements in the UK construction industry, HMSO.

Loushine, T. W., Hoonakker, P. L., Carayon, P., \& Smith, M. J. (2006). Quality and safety management in construction. Total Quality Management and Business Excellence, 17(9), 1171-1212.

Mansir, D. (2014). The Application of Health and Safety Plan in Nigerian Construction Firms. Jordan Journal of Civil Engineering, 8(1), 81-88.

Mohamed, S., \&Chinda, T. (2011). System dynamics modelling of construction safety culture. Engineering, Construction and Architectural Management, 18(3), 266-281.

Muhammad, B. A., Abdulateef, I., Ladi, \& Dorothy, B. (2015). Assessment of Cost Impact in Health and Safety on Construction Projects. American Journal of Engineering Research (AJER), 4(3), 25-30.

Muiruri, G., \&Mulinge, C. (2014). Health and SafetyManagement on ConstructionProjects sites in Kenya ACaseStudy of ConstructionProjects in Nairobi County. In Proceedings of FIG Congress: Engaging the Challenges-Enhancing the Relevance.Kuala Lumpur, Malaysia 16-21 June 2014

Okoye, P. U. (2018). Occupational health and safety risk levels of building construction trades in Nigeria. Construction Economics and Building, 18(2), 92.

Okoye, P. U., \&Okolie, K. C. (2014). Exploratory Study of the Cost of Health and Safety Performance of Building Contractors in South-East Nigeria. British Journal of Environmental Sciences, 2(1), 21-33.

Okoye, P. U., Ezeokonkwo, J. U., \&Ezeokoli, F. O. (2016). Building Construction Workers’ Health and Safety Knowledge and Compliance on Site. Journal of Safety Engineering, 5(1), 17-26.

Olatunji, O. A., Aje, O. I., \&Odugboye, F. (2007). Evaluating Health and Safety Performance of Nigerian Construction Site. CIB World Building Conference (pp. 1176-1190). Accra: CIB World Building Press.

Olutuase, S. O. (2014). A Study of Safety Management in the Nigerian Construction Industry. Journal of Business and Management, 16(3), 1-10.

Opara, P. N. (2007). Building failures and collapses: A case study of Portharcourt, Nigeria. Journal of Technology and Education in Nigeria, 12(1), 35-39.

Ringen, K., Van Duivenbooden, J.C. \&Melius, J. (2010). Construction Safety and Health - Foreword, American Journal of Industrial Medicine, 53, p. 551.

Smallwood J., Haupt T. \&Shakantu. (2008). Construction health and safety in South Africa: Status and recommendations. CIDB report.

Umeokafor, N., Isaac, D., Jones, K., \&Umeadi, B. (2014). Enforcement of Occupational Safety and Health Regulation in Nigeria: an Exploration. European Scientific Journal, 93-105.

Vukomanovic, M., Ceric, A., \&Radujković, M. (2007). BSC-EFQM Based Approach for Performance 
Benchmarking in Construction Industry. Association of Researchers in Construction Management, (pp. 631-640). Belfast, UK: Annual ARCOM Conference.

Vukomanovica, M., Radujkovica, M., \&Nahoda, M. M. (2014.). EFQM ExcellenceModel as the TQM Model of the ConstructionIndustry of South Eastern Europe. Journal of Civil Engineering and Management, 70-81.

Watson, P. (2002). Implementing the European Foundation for Quality Management. TS1.1 Business Practices, 18.

Zhang, S., Teizer, J., Lee, J. K., Eastman, C. M., \&Venugopal, M. (2013). Building information modeling (BIM) and safety: Automatic safety checking of construction models and schedules. Automation in Construction, 29, 183-195. 